\title{
Relationship between the biomass of reef shark and fish in South Morotai Waters, North Maluku, Indonesia
}

\author{
JIBRIEL FIRMAN SOFYAN ${ }^{1}$, AMBARIYANTO AMBARIYANTO ${ }^{1}$, KEN SUWARTIMAH ${ }^{1}$, \\ ABDUL HAMID A. TOHA ${ }^{2, \varphi}$ \\ ${ }^{1}$ Department of Marine Science, Faculty of Fisheries and Marine Science, Universitas Diponegoro. Jl. Prof. Soedharto, SH., Kampus Undip Tembalang, \\ Semarang 50275, Central Java, Indonesia \\ ${ }^{2}$ Department of Fisheries, Faculty of Fisheries and Marine Science, Universitas Papua. Jl. Gunung Salju Amban, Manokwari 98314, West Papua, \\ Indonesia. Tel./fax.: +62-986-211430, `email: h.toha@unipa.ac.id
}

Manuscript received: 13 August 2020. Revision accepted: 4 November 2020.

\begin{abstract}
Sofyan JF, Ambariyanto A, Suwartimah K, Toha AHA. 2020. Relationship between the biomass of reef shark and fish in South Morotai Waters, North Maluku, Indonesia. Biodiversitas 21: 5605-5613. This study aims to determine the biomass of reef shark and fish in South Morotai Waters in North Maluku, Indonesia. The Audible Stationary Count and Underwater Visual Census method were used to collect the data of reef sharks and fish. Seven and one site locations of coral reef and shark ecosystems were surveyed and, the data were analyzed using regression analysis to obtain a correlation between the variables. The three reef sharks found were Carcharhinus melanopterus, Triaenodon obesus, and Carcharhinus amblyrhynchos. Biomass estimation of reef sharks and fish ranged from 0.59 to 19.97 $\mathrm{kg} / \mathrm{ha}$ and $30.95 \mathrm{~kg} / \mathrm{ha}$ to $49.92 \mathrm{~kg} / \mathrm{ha}$, consisting of 8 families. In the area of aggregations, both species were found in 7 sites, and the population of reef shark amounted to $86.96 \mathrm{~kg} / \mathrm{ha}$ and fish was around $55.705 \mathrm{~kg} / \mathrm{ha}$, consisting of 9 families. There was a positive relationship between the biomass of reef shark and fish in South Morotai waters, and the index of determination was 0.8043, showing that the biomass of reef shark was influenced by that of fish. These results indicated the importance of biomass in determining the functional composition and diversity of reef shark and fish.
\end{abstract}

Keywords: Audible stationary count, biomass, correlation, reef fish, reef shark, South Morotai

\section{INTRODUCTION}

Sharks are important organisms found in the ocean ecosystem, especially in structure of reef food webs (Ferretti et al. 2010). Roff et al. (2016) identified some potential ecological functions of sharks on coral reefs, such as nutrient cycling (Schmitz et al. 2010), scavenging (Wilson and Wolkovich 2011), habitat disturbance (Begg et al. 2003), and the removal of invasive species (Wallach et al. 2015). Marine organisms carry out a diverse range of trophic roles in coral reef ecosystems (Roff et al. 2016), as apex predators (Heupel et al. 2014; Roff et al. 2016) or high-level mesopredators (Frisch et al. 2016; Roff et al. 2016), and also labelled generically as 'apex', 'top predators', or 'generalist top predators' (Ceccarelli and Ayling 2010; Hasan and Widodo 2020). The sharks in food webs exert a powerful influence over other species in the lower levels (Bornatowski et al. 2014), and are distributed over a broad range of habitats in every ocean. Those from Carcharhinidae Family are found in reefs' community to a certain extent, with a few occurring in freshwater environments (Iqbal et al. 2019; Hasan and Widodo 2020). Some of the species inhabit the coral reef ecosystems, namely whitetip (Triaenodon obesus), grey (Carcharhinus amblyrhynchos), and blacktip reef shark (Carcharhinus melanopterus) (Carrier et al. 2010), and they move over relatively large areas, often the entire community (Heupel et al. 2014).
Reef fish represent the most diverse assemblages of vertebrates on the planet, and their diversity was found at every local scales, therefore, hundreds of species co-occur within relatively small areas. They also have the broadest geographical distributions (Choat and Russell 2008), and their community plays critical functional roles, such as the main component in aquatic ecosystems (Nabil et al. 2018) and as protein source (Duffy et al. 2016). These vertebrates are indicators for coral condition (Nabil et al. 2018), also, they are important predators or grazers in their community. They are the largest number of organisms and a constituent of the community structure in coral reef ecosystems. One cause of the high diversity in this community is habitat variation (Agrra 2020).

Biomass, which is the total weight of fish per unit area, is related to evenness and the environment (Maureaud et al. 2019). Fish biomass at the community and ecosystem scales is an important indicator for trophic structure, the overall reproductive output of fish, stock status, fishing pressure, habitat conditions, and recruitment success of reef (Agrra 2020). This indicator is a key proxy for coral reefs (McClanahan et al. 2016). The biomass of shark and fish, is a primary driver of coral reef ecosystem services (McClanahan et al. 2016), their diversity plays a role in maintaining reef structure and processes (McClanahan et al. 2011; Chong-Seng et al. 2014). The estimates of fish biomass, their spatial distribution, and recovery potential are important for evaluating reef status, and setting management targets (McClanahan et al. 2016). 
One of the Interactions between species in a community is the meal-consuming activity, and this process eventually forms a food web in the ecosystem. In tropical waters, there are five components of food web (Ruppert et al. 2016) as follows, the primary producers, namely phytoplankton are eaten by zooplankton. Then small fish that eat plankton and macroalgae (herbivores and planktivores) or both eaters (omnivores) occupy the 3rd trophic level. The bigger fish acting as a carnivorous animal (carnivore) occupy the 4th and 5th trophic levels. The top predators are found at the peak of the food web (Link et al. 2012), and reef fish abundance is closely related to this level. Theoretically, large sharks as top predators help in restoring the health of coral reefs indirectly by preying on predatory fish of lower trophic levels. Carnivorous fish has a great opportunity as the main prey of sharks, because its existence is the most found on coral reef ecosystems (Mukharror et al. 2017). However, a critical evaluation of the available empirical studies (Roff et al. 2016) showed that shark-herbivore interactions occur relatively infrequently on most presentday reefs (Rizzari et al. 2015).

South Morotai in North Moluccas has rich marine ecosystems with corals, reef fish, and sharks (Ministry of Marine Affairs and Fisheries, Republic of Indonesia, and USAID Sustainable Ecosystems Advanced Project 2018).
This area has been identified as a priority for sustainable fisheries management (Retnoningtyas et al. 2017). Many studies have investigated the reef fish (Nabil et al. 2018) and sharks (Pridina 2015; Ichsan et al. 2016; Mukharror et al. 2019; Mukharror et al. 2020), and also their relative abundance (Mukharror et al. 2018). However, no study has yet measured the relationship between the biomass of reef fish and shark. Therefore, this research is essential for improving basic management action to conserve or enhance ecosystem resilience. An important step in this study is to understand reef shark and fish biomass, as well as to examine their relationship at the trophic level (Graham et al. 2015; Mouillot et al. 2016; McClanahan and Jadot 2017). For this reason, this study aims to determine the biomass of both species in South Morotai Waters in North Moluccas.

\section{MATERIALS AND METHODS}

\section{Study area}

Observations of reef sharks and fish were performed at 8 locations with several considerations, such as the existence of coral reefs, their depths, and the information on sharks appearance (Table 1, Figure 1).

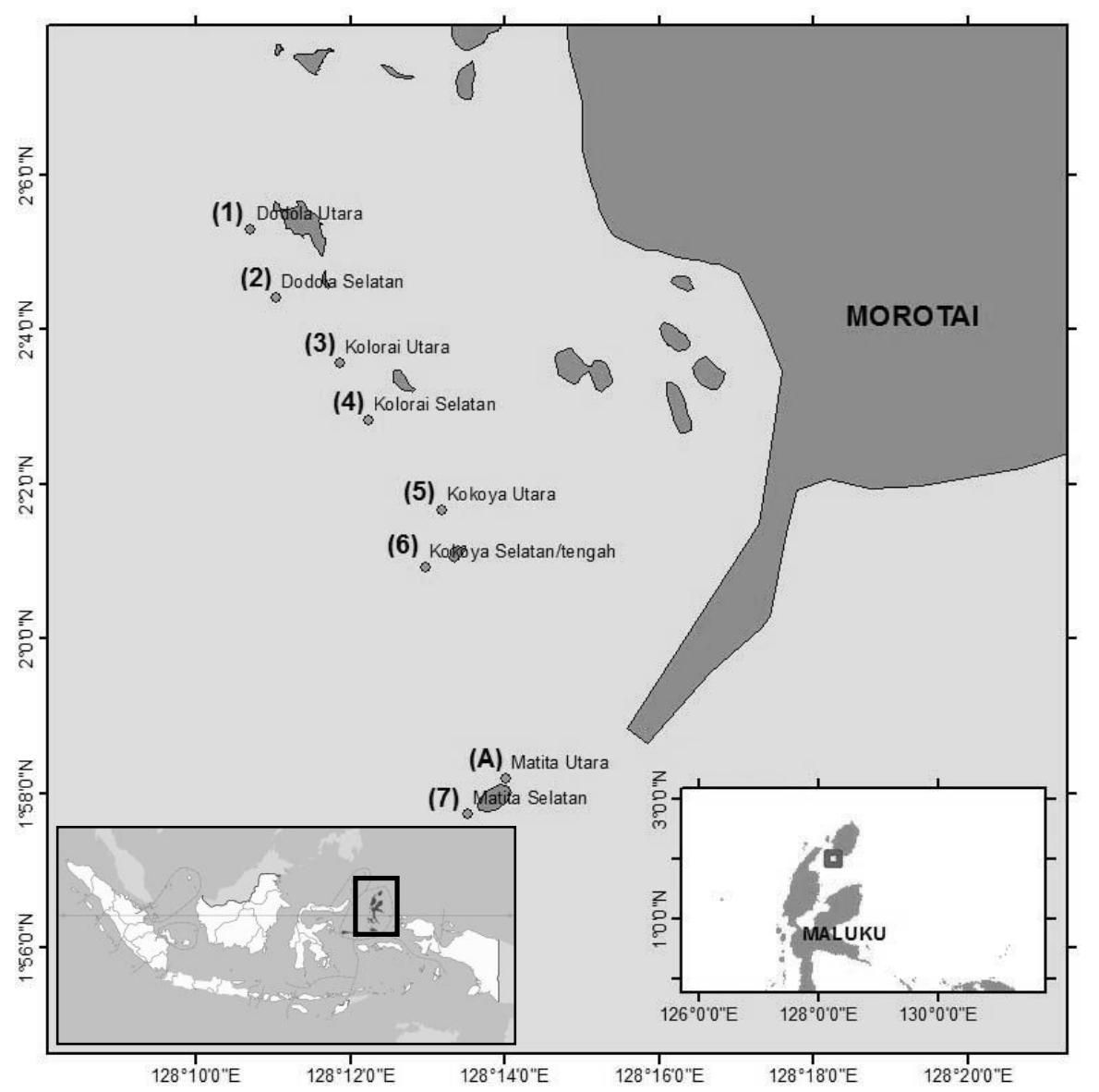

Figure 1. Location of reef shark and fish observation in South Morotai Waters, North Maluku Province, Indonesia. The seven locations observed were: 1. Dodola Utara; 2. Dodola Selatan; 3. Kolorai Utara; 4. Kolorai Selatan; 5. Kokoya Utara; 6. Kokoya Selatan; 7. Matita Selatan, and was carried out at a particular site that was suspected as shark aggregation areas in South Morotai at Matita Utara (A) 
Table 1. Research locations in South Morotai Waters, North Maluku Province, Indonesia

\begin{tabular}{lll}
\hline Site location & Latitude $(\mathbf{N})$ & Longitude $(\mathbf{E})$ \\
\hline Dodola Utara & $2^{0} 05^{\prime} 33.66^{\prime}$, & $128^{0} 10^{\prime} 52.18^{\prime}$, \\
Dodola Selatan & $2^{0} 04^{\prime} 36.09^{\prime}$, & $128^{0} 11^{\prime} 10.40^{\prime}$, \\
Kolorai Utara & $2^{0} 03^{\prime} 23.71^{\prime}$, & $128^{0} 12^{\prime} 23.09^{\prime}$, \\
Kolorai Selatan & $2^{0} 02^{\prime} 52.98^{\prime}$, & $128^{0} 12^{\prime} 28.40^{\prime}$, \\
Kokoya Utara & $2^{0} 01^{\prime} 21.01^{\prime}$, & $128^{0} 13^{\prime} 24.78^{\prime}$, \\
Kokoya Selatan & $2^{0} 00^{\prime} 48.32^{\prime}$, & $128^{0} 13^{\prime} 14.57^{\prime}$, \\
Matita Utara & $1^{0} 58^{\prime} 04.87^{\prime}$, & $128^{0} 14^{\prime} 06.15^{\prime}$, \\
Matita Selatan & $1^{0} 57^{\prime} 47.53^{\prime}$, & $128^{0} 13^{\prime} 39.03^{\prime}$, \\
\hline
\end{tabular}

\section{Data collection}

Audible stationary count (ASC) method was used during observations of reef sharks (Frisch 2013). The working principle was to use an empty plastic bottle which was repeatedly squeezed to generate a low-frequency sound for attracting sharks to the point of diver's station. The distance of shark response in the ASC method was 80 $\mathrm{m}$. The observation area (AoA) was calculated using the formula by Frisch (2013), and the reef sharks were identified to the species level.

Reef fish data collections were carried out using underwater visual census (UVC) (English et al. 1997) with an imaginary line along $5 \mathrm{~m}$ for small (total length 10-35 $\mathrm{cm}$ ) and $20 \mathrm{~m}$ for large fish (total length $\geq 35 \mathrm{~cm}$ ), and stretched along the belt transect of $50 \mathrm{~m}$ at depth 10-12 m in each site. Observations were performed by counting each individual and identifying them in their family level, and also estimating the total length of each fish, which produce more precise results for assessing their abundance and biomass (Juhel et al. 2017).

\section{Data analysis}

The output from the data processing included the value of density and biomass at each site location. The density value (per ha) was calculated using the formula by Wilson and Green (2009). Both reef fish and shark biomass were estimated using the length-weight equation, $\mathrm{W}=\mathrm{aL}^{\mathrm{b}}$ as described by Kulbicki et al (2005), where W= fish weight in grams $(\mathrm{g}), \mathrm{L}=$ Total length of fish in centimeter $(\mathrm{cm})$, a and $b=$ constant of species. The biomass in hectares was evaluated for each site using the formula by Wilson and Green (2009). The correlation analysis was performed using the regression procedure, which aimed to determine the relationship between the biomass of reef shark and fish.

\section{RESULTS AND DISCUSSION}

\section{Biomass of reef shark}

A total of 15 sharks were observed on the ASC, across 7 different locations, namely Dodola Utara $(n=3)$, Dodola Selatan $(n=3)$, Kolorai Utara $(n=4)$, Kolorai Selatan $(n=$ 1), Kokoya Utara $(\mathrm{n}=1)$, Kokoya Selatan $(\mathrm{n}=2)$, and Matita Selatan $(n=1)$ (Table 2). Three species of reef sharks were found including the Carcharinidae family, namely Carcharhinus melanopterus, Triaenodon obesus, and Carcharhinus amblyrhynchos. They were the most known reef-generalist species, and include the larger and more mobile living year-round on corals (Heupel et al. 2019). The diversity of reef sharks was also dominated by the same three species in the Solomon Islands (Goetze et al. 2018) and in Palmyra Atoll (Stevenson et al. 2006). According to Carrier et al. (2010), sharks of the Carcharhinidae family settled on coral reefs, namely $T$. obesus, C. amblyrhynchos, and C. melanopterus. These results were different from those observed by Juhel et al. (2017) in New Caledonia (South-Western Pacific) (9 species), Mourier et al. (2016) in Fakarava Atoll (French Polynesia) (5 species), and Mukharror et al. (2017) in South Morotai, observed that there were two species of reef shark and none of the C. amblyrhynchos.

The largest reef shark observed was $C$. amblyrhynchos $(130 \mathrm{~cm})$ in Matita Selatan and the smallest was C. melanopterus $(50 \mathrm{~cm})$ in Kokoya Utara and Selatan. The total length across all species for C. amblyrhynchos was $130 \mathrm{~cm}, C$. melanopterus was $75.7 \mathrm{~cm}$ and T. obesus was $85 \mathrm{~cm}$. Body size was an important determinant of ecological role, fitness in fishes (Barley et al. 2017), and influences predator-prey interactions (Dobashi et al. 2018). C. amblyrhynchos was found only in Matita Selatan $1.3 \mathrm{~m}$ in size and $15.5 \mathrm{~kg} / \mathrm{ha}$ in biomass. This length was categorized as sexual maturity size. According to Froese and Pauly (2019), C. amblyrhynchos with adult sizes ranged from 92 to $142 \mathrm{~cm}$. Moreover, this species was less than $1.9 \mathrm{~m}$ long (Compagno 1984), while Bester (2009) reported that its maximum length and weight were $2.6 \mathrm{~m}$ and $33.7 \mathrm{~kg}$. C. melanopterus total length varies from $50 \mathrm{~cm}$ in Kokoya (Utara and Selatan) to $110 \mathrm{~cm}$ in Dodola Selatan, and its biomass ranged from 0.59 to 9.4 $\mathrm{kg} / \mathrm{ha}$. C. melanopterus typically attained a length of 1.5 (Chin et al. 2013) or $1.6 \mathrm{~m}$ (Corrigan and Naylor 2018), while its maximum reported weight was $13.550 \mathrm{~kg}$ (IGFA 2001). Its length at maturity ranged from 91-120 cm (Froese and Pauly 2019). Their adult females ranged in size from 101 to $160 \mathrm{~cm}$ TL $($ mean $=147.0 \mathrm{~cm}$ TL) (Rhodes et al. 2019). Then $50 \mathrm{~cm}$ TL was similar to its size at birth ranging from $33-52 \mathrm{~cm}$ (Compagno 1984). Meanwhile, T. obesus in Morotai has $85 \mathrm{~cm}$ TL and $2.5 \mathrm{~kg} / \mathrm{ha}$ in biomass, relatively small species, and few were longer than $1.6 \mathrm{~m}$. Its maximum length was often given as $2.1 \mathrm{~m}$, though this was originally based on visual observations and sometimes dubious (Randall 1977). The maximum reported weight was $18.3 \mathrm{~kg}$ (IGFA 2001). The positive association with fish biomass was independent of body size (Maire et al. 2018).

The biomass of the reef shark ranged from 0.59 to $19.97 \mathrm{~kg} / \mathrm{ha}$, the highest was $19.97 \mathrm{~kg} / \mathrm{ha}$ in Dodola Selatan and the lowest was $0.59 \mathrm{~kg} / \mathrm{ha}$ in Kokoya Utara (Figure 2).

There were several physicals, structural (Gove et al. 2013), and coral reef conditions (Coral Triangle Center 2017) differences that vary across locations explaining the variation in reef shark diversity and biomass. And was found to vary from worse and moderate to good in several islands of Morotai (Coral Triangle Center 2017; Purba et al. 2019). Coral-reef health is an essential driver for the abundance of sharks (Espinoza et al. 2014). In some places, there was much coral rubble, possibly from those destroyed by boat anchors or dynamite fishing. On the other side of the island, around Matita, Kokoya, and Dodola, there were some spots with good healthy corals (Coral Triangle Center 2017). 
Table 2. Reef Shark found in 7 locations

\begin{tabular}{lcccc}
\hline \multicolumn{1}{c}{ Site Location } & $\mathbf{n}$ & \multicolumn{1}{c}{ Species } & Total length (cm/ind.) & Biomass (kg/ha/ind.) \\
\hline Dodola Utara & & C. melanopterus & 75 & 2.458 \\
& 3 & C. melanopterus & 75 & 2.458 \\
& & C. melanopterus & 75 & 2.458 \\
Dodola Selatan & & C. melanopterus & 60 & 11.237 \\
& 3 & C. melanopterus & 110 & 94.214 \\
Kolorai Utara & & C. melanopterus & 110 & 94.214 \\
& & C. melanopterus & 55 & 0.8281 \\
& & C. melanopterus & 55 & 0.8281 \\
Kolorai Selatan & 4 & C. melanopterus & 100 & 67.439 \\
Kokoya Utara & & T. obesus & 85 & 25.481 \\
Kokoya Selatan & 1 & C. melanopterus & 90 & 46.601 \\
& 1 & C. melanopterus & 50 & 0.5927 \\
& 2 & C. melanopterus & 50 & 0.5927 \\
\end{tabular}

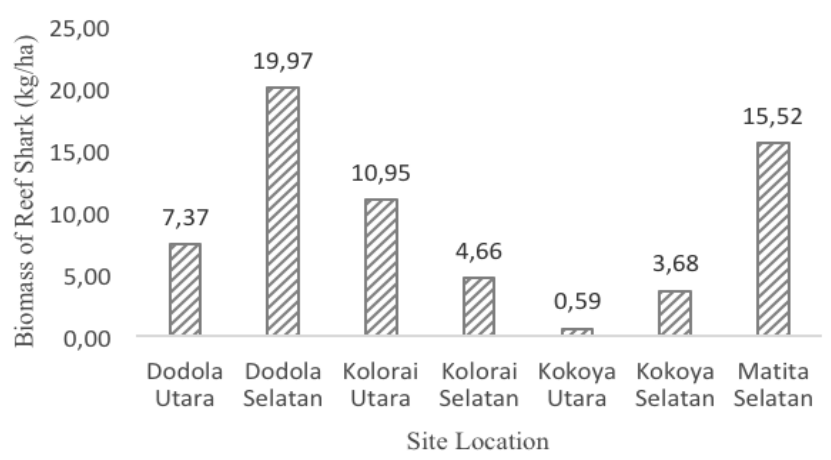

Figure 2. Biomass of reef shark (Carcarhinidae) in 7 site locations

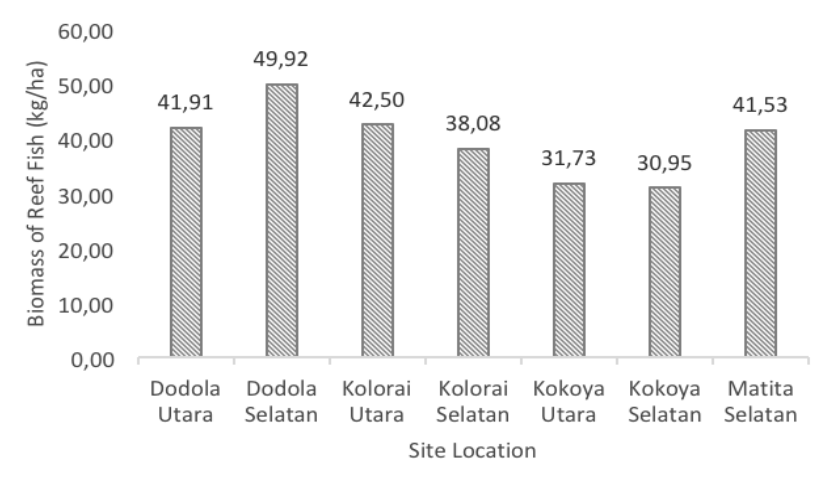

Figure 3. Biomass of reef fishes in 7 site locations

\section{Biomass of reef fish}

Reef fish biomass varied across locations from 30.95 $\mathrm{kg} / \mathrm{ha}$ to $49.92 \mathrm{~kg} / \mathrm{ha}$. Reef fish biomass was highest at Dodola Selatan (2) amounting to $49.92 \mathrm{~kg} / \mathrm{ha}$ and consisting of 8 families. Two site locations with the lowest value of fish biomass were Kokoya Selatan (6) with the value of $30.95 \mathrm{~kg} / \mathrm{ha}$ and Kokoya Utara (5) amounting to $31.73 \mathrm{~kg} / \mathrm{ha}$ (Figure 3).
Both locations consisted of 6 families. In other oceans, reef fish biomass ranged from $7500 \mathrm{~kg} / \mathrm{ha}$ for the Chagos Islands (Graham and McClanahan 2013) to $<600 \mathrm{~kg} / \mathrm{ha}$ in various fisheries (McClanahan and Abunge 2015). Based on community-wide scan approach, Maire et al. (2018) showed that a median level of reef fish biomass was higher (560 kg/ha, range: $439-773 \mathrm{~kg} / \mathrm{ha}$ ) than that observed when there was absent of crucial species $(370 \mathrm{~kg} / \mathrm{ha}$, range: 337 $385 \mathrm{~kg} / \mathrm{ha})$.

This study showed that reef fish biomass at South Morotai was more scarce than other locations, and was positively associated with their habitat structural complexity (Graham and Nash 2013). Many factors affected the value of fish biomass abundance, live coral cover, substrate diversity, and structural complexity (Kulbicki et al. 2005). The abundances of coral reef fishes were driven by both top-down and bottom-up processes and changes in the trophic structure were attributed to one of these processes, assuming both were quantified simultaneously (Conversi et al. 2015). According to Vincent et al. (2011), benthic cover and fishing intensity influenced the biomass of herbivorous fish communities more on the reefs, while reef type has little effect on herbivore fish biomass. Moreover, Vincent et al. (2011) assumed that a factor other than reef geomorphology was responsible for the observed differences in herbivorous fish populations. Robinson et al. (2016) asserted that temperature and oceanic productivity were both strong and have positive influences on reef fish biomass.

This study observed 8 distinct families of reef fishes, such as Acanthuridae (surgeonfish), Caesionidae (fusilier), Carangidae (trevally), Haemulidae (sweetlips), Lutjanidae (snapper), Scaridae (parrotfish), Serranidae (grouper), and Siganidae (rabbitfish). All the families, except Scaridae, were significantly and positively related to coral cover (Maire et al. 2018). Out of these eight families, the Acanthuridae, Scaridae, Siganidae, Caesionidae, and Lutjanidae were always found in every location. The previous study has shown different results with both 14 (Nabil et al. 2018) and 32 families (Mukharror et al. (2017). 
Three families classified as mesopredator functional groups were Haemulidae, Serranidae, and Lutjanidae. Both Lutjanidae and Serranidae (snapper and grouper respectively) were omnivorous and opportunistic carnivores. Family Scaridae was classified as an excavator and scraper functional group. While the families of Acanthuridae and Siganidae were classified as detritivore or algal cropper functional group (Cooper et al. 2019). The Carangidae were also classified as predatory fishes (Choat and Russell 2008). The Acanthuridae, Scaridae, and Siganidae were classified as herbivorous groups. According to Puk et al. (2016), the coral reefs in the IndoPacific region were dominated by herbivorous fish mainly from the family of Acanthuridae, Scaridae, and Siganidae. The three families were predominantly grazers (Vincent et al. 2011; Cooper et al. 2019) and play an essential role in maintaining resilience in coral reefs by limiting the growth of macroalgae (Hughes et al. 2007) and creating sufficient available substrate for planulae settlement (Bonaldo and Bellwood 2009).

The family of Lutjanidae (snapper) is an economically important fish used in the fisheries. In ecology, they are predators fish grouped under apex predators. This family always gathered in large numbers in the shallow waters of the coral reef ecosystem when foraging, and it has become one cause of biomass in Lutjanidae, greater than other families (Froese and Pauly 2020). Caesionidae, classified as planktivorous functional groups (Cooper et al. 2019), also contributed significantly to the value of biomass in each site location. Although this family has relatively small individual sizes with an average $<30 \mathrm{~cm}$, an abundance of these fish was found in groups (schooling) that positively contributed to the value of biomass. This family has dependence on the current which brought zooplankton as a source of food. Their role in ecology is connected to the food chain on coral reef ecosystems to open water areas. However, only four families (Acanthuridae, Labridae, Lutjanidae, and Serranidae) presented key species, significantly associated with fish biomass. Besides, only six functional entities were familiar and significantly associated with biomass, namely small and medium herbivores, small planktivores, medium and large fishes targeting mobile invertebrates, and mesopredators (Maire et al. 2018).

\section{Reef shark and reef fish biomass in aggregation areas}

Reef sharks have been reported to aggregate locally over shallow reef areas in Matita Utara. This Island has quite good coral reef conditions as well as an area known for schooling blacktip reef-shark (Coral Triangle Center 2017). On this island, 13 sharks were found consisting of only one species, which was $C$. melanopterus. Weideli et al. (2015) also observed the foraging events on the aggregation area by $C$. melanopterus at the Moorea island.

Each shark has a size of the total length variety from 75 to $120 \mathrm{~cm}$. The biomass of $C$. melanopterus was recorded along the island, values ranged from $2.46 \mathrm{~kg} / \mathrm{ha}$ to 12.78 $\mathrm{kg} / \mathrm{ha}$. The total reef shark biomass was $86.96 \mathrm{~kg} / \mathrm{ha}$ (Table $3)$.
Matita island is a small place known for schooling blacktip reef-shark (Coral Triangle Center 2017). On this island, aggregation events influenced the movement patterns and activity of reef sharks. Aggregation behavior is a special condition in Matita Utara (A) made possible by different factors. During spawning season, reef shark daily detections increased, indicating the use of this technique for foraging by elasmobranchs (Rhodes et al. 2019). The factors associated with an abundance of reef sharks were prey or reproductive activities (Mourier and Planes 2013). And according to Heupel (2010), the functions relating to the aggregation behavior of sharks were reproduction or mating and a form of predator avoidance.

Nine families of demersal fishes largely dominate the reef of Matita Utara, three herbivorous (Siganidae, Acanthuridae, and Scaridae), and five carnivorous (Serranidae, Lutjanidae, Carangidae, Haemulidae, and Lethrinidae). Caesionidae was closely related to Lutjanidae and possessed several planktivorous modes of life (Carpenter 1988). Generally, biomass is mostly dominated by Acanthuridae, followed by Caesionidae, Siganidae, Lethrinidae, Carangidae, etc. (Table 4). The average biomass of reef fish in the shark aggregation area was 55.7 $\mathrm{kg} / \mathrm{ha}$. The biggest contributors to biomass in the site location were Acanthuridae (230 kg/ha) and Siganidae (54 $\mathrm{kg} / \mathrm{ha}$ ) as herbivorous fish. The substrate in the reef of Matita was characterized by a dominance of live-algae, and its combination with healthy reef and predators, as well as both juvenile and adult fish of all types, explained the dominance of its herbivorous family, followed by the sharks and both planktivorous and carnivorous.

Both reef sharks and fish biomass have high biomass $(86.9 \mathrm{~kg} / \mathrm{ha}$ and $55.7 \mathrm{~kg} / \mathrm{ha}$, respectively), correlating with the findings that coral reef ecosystems with top predator levels supported high levels of herbivores (Mumby et al. 2006; Stevenson et al. 2006). In Matita Utara, reef shark $(86.9 \mathrm{~kg} / \mathrm{ha})$ was the dominant fishes in biomass and higher than that of fish $(55.7 \mathrm{~kg} / \mathrm{ha})$.

Table 3. Biomass of C. melanopterus in aggregation areas (A. Matita Utara)

\begin{tabular}{ccc}
\hline $\mathbf{n}$ & Total length $(\mathbf{c m})$ & Biomass $(\mathbf{k g} / \mathbf{h a})$ \\
\hline 1 & 100 & 6.7439 \\
1 & 100 & 6.7439 \\
1 & 100 & 6.7439 \\
1 & 120 & 12.7844 \\
1 & 80 & 3.0828 \\
1 & 80 & 3.0828 \\
1 & 85 & 3.8134 \\
1 & 85 & 3.8134 \\
1 & 90 & 4.660 \\
1 & 115 & 11.0113 \\
1 & 115 & 11.0113 \\
1 & 115 & 11.0113 \\
1 & 75 & 2.4582 \\
Total & $\mathbf{1 3}$ & $\mathbf{8 6 . 9 6 1 2}$ \\
\hline
\end{tabular}


Table 4. Average of reef fish biomass in aggregation areas (A. Matita Utara)

\begin{tabular}{lc}
\hline \multicolumn{1}{c}{ Family } & Biomass $(\mathbf{k g} / \mathbf{h a})$ \\
\hline Acanthuridae & 230.970 \\
Caesionidae & 62.150 \\
Carangidae & 35.226 \\
Haemulidae & 22.872 \\
Lethrinidae & 46.658 \\
Lutjanidae & 22.534 \\
Scaridae & 7.086 \\
Serranidae & 19.666 \\
Siganidae & 54.189 \\
Average of biomass & 55.705 \\
\hline
\end{tabular}



Figure 4. Regression model of reef fish and shark biomass

\section{Relation of reef shark biomass and reef fishes biomass}

Results from this analysis showed the distribution of the data forming linear trend with a positive correlation between the biomass of reef sharks and fish biomass. The coefficient of determination $\left(\mathrm{R}^{2}\right)$ was 0.8043 or $80.43 \%$, indicating that there was a healthy relationship. It shows, great reef shark biomass also had a high biomass of reef fish. This result supported the general hypothesis that ecosystems with many predators (reef sharks) have much herbivorous fish (reef fish) (Stevenson et al. 2006). The regression model showed that the increase in reef fishes biomass increased with shark.

The abundance of these reef fishes was important as an early indication of shark existence in South Water of Morotai Island (Mukharror et al. 2017). Frisch et al. (2016) and McCauley et al. (2012) asserted that reef sharks are important predator connecting lagoons to habitats and offshore ecosystems, and exerting predation influence over a range of taxa. Reef shark assemblages include both reefdependent species, such as $C$. amblyrhynchos, $C$. melanopterus, and T. obesus (Frisch et al. 2016).

Reef shark and fish are often associated with coral ecosystem. They were both consumers which either directly or indirectly depend on primary producers for food energy. They also have predator-prey relationships, which was the interactions between two species where one was the hunted food source for the other. The organism that feeds was called the predator and the organism that was fed upon was the prey. Some reef sharks were predators for reef fish's families, such as Caesinidae, Carangidae, Serranidae (Froese and Pauly 2020). While reef fish families were also predator for other nekton, crustaceans, mollusks, echinoderms, polychaetes, and categorized as a carnivorous, namely Serranidae (Speed et al. 2019), Carangidae (Speed et al. 2019; Froese and Pauly 2020), Lutjanidae (Anderson and Allen 2001), and Lethrinidae (Speed et al. 2019). In contrast, Siganidae, Acanthuridae, and Scaridae were grazers or herbivorous fishes (Vincent et al. 2011), and were predators in the food chain. Roff et al. (2016) showed that sharks occupy a diverse range of trophic roles in coral reef ecosystems. The trophic positions vary substantially among species, size class, habitat use, behaviour, and ontogeny (Heupel et al. 2014).

The presence of reef sharks affected the formation of trophic ecology on a coral ecosystem (Ferretti et al. 2010; Roff et al. 2016), such as apex or meso-predators (Osgood and Baum 2015; Roff et al. 2016). Furthermore, keeping the abundance, distribution, and diversity of species, also provides an important food source for scavenger organisms and eliminating a sick and weak organism in a population (Lynam et al. 2017). According to Wallach et al. (2015), apex predators are usually large-bodied animal that occupy the highest trophic level. Roff et al. (2016) asserted that reef sharks did not act as apex predators, instead functioned as mesopredators along with a diverse group of fish. There was an interaction strength between reef sharks and their prey that impacts the ecosystem dynamics. In addition, Roff et al. (2016) stated that reef fish and shark interaction was dependent on population abundance, body size, trophic level, and diet specialisation.

\section{Conservation and management}

The presence of reef sharks was inseparable from threat, because the waters of South Morotai did not have marine protected areas which provide a potential fishing site (Dharmadi et al. 2015). According to the International Union for the Conservation of Nature (IUCN), $C$. melanopterus, C. amblyrhynchos, and T. obesus were considered near threatened, and also vulnerable to negative impacts of fishing pressure and habitat destruction (Heupel 2009; Smale 2009).

In addition, based on the IUCN Red List, some species in the distinct families of reef fish in South Morotai were in threatened categories globally. One specie in the Acanthuridae family was listed as vulnerable (Myers et al. 2012), also, one Carangidae specie was labelled as near threatened (Carpenter et al. 2018) and three as vulnerable (Smith-Vaniz et al. 2015; Smith-Vaniz et al. 2018a; SmithVaniz et al. 2018b). The family of Lutjanidae contained five threatened species, two were listed as near threatened (Lindeman et al. 2016a; Lindeman et al. 2016b) and three as vulnerable (Anderson et al. 2015a; Lindeman et al. 2016c; Lindeman et al. 2016d). Three species in the Serranidae were listed as endangered, (Robertson et al. 2010; Anderson et al. 2015b; Moran and Puebla 2020), 4 as vulnerable (Roberts 1996a; Roberts 1996b; Smith-Vaniz et al. 2010; Smith-Vaniz et al. 2010), 4 as near threatened (Acero 1996; Cornish 2004; Bearez et al. 2010; Smith- 
Vaniz et al. 2015), 1 as critically endangered (Robertson and Carpenter 2019), and 1 as vulnerable (Carpenter and Smith-Vaniz 2016).

Barley et al. (2017) found that sharks (and also reef fish) were significantly more diverse, abundant, larger in size, and greater in biomass in the marine reserve, relative to the fishing area. The most effective method of maintaining fish species and their ecological roles was to prevent their biomass from falling below a critical level (McClanahan and Jadot 2017). Reef fish biomass is an important driver for the abundance of sharks (Roff et al. (2016). The results indicated the importance of reef shark and fish biomass, their functional composition, and diversity. This suggested a need to manage biomass in order to retain these attributes in the fish community for ecosystem-based management. Protecting and managing fish biomass as opposed to unique locations, is a key recommendation for both conserving and managing the diversity of reef fish and shark in the South Morotai waters, and possibly more broadly. Therefore, Goetze et al. (2018) found that, location was the most important factor influencing reef sharks, which was primarily driven by a significantly greater abundance and biomass in the more remote sites.

\section{ACKNOWLEDGEMENTS}

We are grateful to the Shark Diving Indonesia Co., in Morotai Island, North Maluku, Indonesia for funding this research.

\section{REFERENCES}

Acero A. 1996. Serranus dewegeri. The IUCN Red List of Threatened Species 1996: e.T39304A10187156. DOI: 10.2305/IUCN.UK.1996.RLTS.T39304A10187156.en.

AGRRA (Atlantic and Gulf Rapid Reef Assessment). 2020. Fish Indicators. https://www.agrra.org/coral-reef-monitoring/fishindicator/

Anderson WDJr, Allen GR. 2001. Lutjanidae. Jobfishes. In: Carpenter KE, Niem V (eds). FAO Species Identification Guide for Fishery Purposes. The living marine resources of the Western Central Pacific. Vol. 5. Bony fishes part 3 (Menidae to Pomacentridae). FAO, Rome.

Anderson W, Carpenter KE, Gilmore G, Bustamante M, Robertson GR 2015b. Hypoplectrus castroaguirrei. The IUCN Red List of Threatened Species 2015: e.T47149690A47461836. DOI: 10.2305/IUCN.UK.2015-2.RLTS.T47149690A474-61836.en.

Anderson W, Claro R, Cowan J, Lindeman K, Padovani-Ferreira B, Rocha LA. 2015a. Lutjanus campechanus (errata version published in 2017). The IUCN Red List of Threatened Species 2015: e.T194365A115334224. DOI: 10.2305/IUCN.UK.20154.RLTS.T194365A2322724.en.

Barley S, Meekan MG, Meeuwig JJ. 2017. Species diversity, abundance, biomass, size and trophic structure of fish on coral reefs in relation to shark abundance. Mar Ecol Prog Ser 565: 163-179. DOI: 10.3354/meps11981.

Bearez P, Merlen G, Rivera F. 2010. Cratinus agassizii. The IUCN Red List of Threatened Species 2010: e.T183659A8153285. DOI: 10.2305/IUCN.UK.2010-3.RLTS.T183659A81532-85.en.

Begg CM, Begg KS, Du Toit JT. 2003. Sexual and seasonal variation in the diet and foraging behaviour of a sexually dimorphic carnivore, the honey badger (Mellivora capensis). J Zool 260: 301-316. DOI: $10.1017 /$ S0952836903003789
Bester C. 2009. Biological Profiles: Grey Reef Shark. Florida Museum of Natural History Ichthyology Department. Retrieved on April 29, 2009.

Bonaldo RM, Bellwood D. 2009. Dynamics of parrotfish grazing scars. Mar Biol 156 (4): 771-777. DOI: 10.1007/s00227-009-1129-x

Bornatowski H, Navia AF, Braga RR, Abilhoa V, Corrêa MFM. 2014. Ecological importance of sharks and rays in a structural foodweb analysis in southern Brazil. ICES J Mar Sci 71 (7): 1586-1592. DOI: 10.1093/icesjms/fsu025

Carpenter KE. 1988. FAO Species Catalogue. Vol. 8. Fusilier fishes of the world. An annotated and illustrated catalogue of caesionid species known to date. FAO, Rome.

Carpenter KE, Jiddawi N, Borsa P, Smith-Vaniz WF, Yahya S, Obota C. 2018. Trachurus japonicus. The IUCN Red List of Threatened Species 2018: e.T20437783A67871570. DOI: 10.2305/IUCN.UK.2018-2.RLTS.T20437783A678-71570.en.

Carpenter KE, Smith-Vaniz WF. 2016. Siganus niger (errata version published in 2017). The IUCN Red List of Threatened Species 2016: e.T69690275A115470334. DOI: 10.2305/IUCN.UK.-2016-3.RLTS.T69690275A69690359.en.

Carrier JC, Musick JA, Heithaus MR. 2010. Biology of Sharks and Their Relatives II. CRC Press, USA.

Ceccarelli D, Ayling T. 2010. Role, Importance and Vulnerability of Top Predators on the Great Barrier Reef-a review. Great Barrier Reef Marine Park Authority, Townsville.

Chin A, Simpfendorfer C, Tobin A, Heupel M. 2013. Validated age, growth and reproductive biology of Carcharhinus melanopterus, a widely distributed and exploited reef shark. Mar Freshw Res 64 (10): 965-975.

Choat JH, Russell BC. 2008. The fish assemblages of the Great Barrier Reef: Their Diversity and Origin. In: Hutchings P, Kingsford M, Hoegh-Guldberg O (eds). The Great Barrier Reef: Biologi, Environment and Management. CSIRO publishing, Collingwood, Australia

Chong-Seng KM, Nash KL, Bellwood DR, Graham NAJ. 2014. Macroalgal herbivory on recovering versus degrading coral reefs. Coral Reefs 33: 409-419. DOI: 10.1007/s00338-014-1134-5

Compagno L. 1984. Sharks of the World. United Nations Development Programme, Rome.

Conversi A, Dakos V, Gårdmark A, Ling S, Folke C, Mumby PJ, Greene C, Edwards M, Blenckner T, Casini M, Pershing A, Möllmann C. 2015. A holistic view of marine regime shifts. Phylosophical Transaction Royal Soc B 370: 8. DOI: 10.1098/rstb.2013.0279

Cooper AM, MacDonald C, Roberts TE, Bridge TCL. 2019. Variability in the functional composition of coral reef fish communities on submerged and emergent reefs in the central Great Barrier Reef, Australia. PLoS ONE 14 (5): e0216785. DOI: 10.1371/journal.pone.0216785

Coral Triangle Center. 2017. Activity Report: Scoping Study at Morotai Islands, North Maluku, Feb 19-26, 2017. USAID Sustainable Ecosystems Advanced (USAID SEA) Project, US.

Cornish A. 2004. Epinephelides armatus. The IUCN Red List of Threatened Species 2004: e.T44679A10923317. DOI: 10.2305/IUCN.UK.2004.RLTS.T44679A10923317.en.

Corrigan S, Naylor G. 2018. Discover Fishes. Carcharhinus melanopterus. Florida Museum of Natural History Ichthyology Department, Florida.

Dharmadi D, Fahmi F, Satria F. 2015. Fisheries management and conservation of sharks in Indonesia. Afr J Mar Sci 37 (2): 249-258. DOI: $10.2989 / 1814232 X .2015 .1045431$

Dobashi T, Iida M, Takemoto K. 2018. Decomposing the effects of ocean environments on predator-prey body-size relationships in food webs. Royal Soc Open Sci 5: 180707. DOI: 10.1098/rsos.180707

Duffy JE, Lefcheck JS, Stuart-Smith RD, Navarrete SA, Edgar GJ. 2016. Biodiversity Enhances Reef Fish Biomass and Resistance to Climate Change. Proceeding of National Academy of Sciences of the United State of America 113 (22): 6230-6235. DOI: 10.1073/pnas.1524465113.

English S, Baker V, Wilkinson C. 1997. Survey Manual for Tropical Marine Resource $2^{\text {nd }}$ edition. Australian Institute of Marine Science, Townsville.

Espinoza M, Cappo M, Heupel MR, Tobin AJ, Simpfendorfer CA. 2014. Quantifying shark distribution patterns and species-habitat associations: Implications of marine park zoning. PLoS One 9: e106885. DOI: 10.1371/journal.pone.0106885 
Ferretti F, Worm B, Britten GL, Heithaus MR, Lotze HK. 2010. Patterns and ecosystem consequences of shark declines in the ocean. Ecol Let 13: 1055-1071. DOI: 10.1111/j.1461-0248.2010.01489.x.

Frisch AJ. 2013. The Dr. Dorothea Sandars and Irene Lee Churchill Fellowship to Develop Robust Methods for Measuring and Monitoring Reef Shark Populations. Fellowship Report No. 158, Winston Churchill Memorial Trust of Australia, Canberra.

Frisch AJ, Ireland M, Rizzari JR, Lo“nnstedt OM, Magnenat KA, Mirbach CE, Hobbs J-PA. 2016. Reassessing the trophic role of reef sharks as apex predators on coral reefs. Coral Reefs 35: 459-472. DOI: 10.1007/s00338-016-1415-2

Froese R, Pauly D. 2019. FishBase. World Wide Web electronic publication. www.fishbase.org

Froese R, Pauly D. 2020. FishBase (version Feb 2018). In: Roskov Y, Ower G, Orrell T, Nicolson D, Bailly N, Kirk PM, Bourgoin T, DeWalt RE, Decock W, Nieukerken E, Penev L (eds.). Digital Resource at www.catalogueoflife.org/col. Species 2000: Naturalis, Leiden, the Netherlands.

Goetze JS, Langlois TJ, McCarter J, Simpfendorfer CA, Hughes A, Leve JT, Jupiter SD. 2018. Drivers of reef shark abundance and biomass in the Solomon Islands. PLoS ONE 13 (7): e0200960. DOI: 10.1371/journal.pone.0200960

Gove JM, Williams GJ, McManus MA, Heron SF, Sandin SA, Vetter OJ, Foley DG. 2013. Quantifying climatological ranges and anomalies for pacific coral reef ecosystems. PLoS ONE 8 (4): e61974. DOI: 10.1371/journal.pone.0061974

Graham NA, Jennings S, MacNeil MA, Mouillot D, Wilson SK. 2015 Predicting climate-driven regime shifts versusrebound potential in coral reefs. Nature 518: 94-97.

Graham NAJ, McClanahan TR. 2013. The last call for marine wilderness? BioSci 63 (5): 397-402.

Graham NAJ, Nash KL. 2013. The importance of structural complexity in coral reef ecosystems. Coral Reefs 32 (2): 315-326. DOI: 10.1007/s00338-012-0984-y.

Hasan V, Widodo MS. 2020. The presence of Bull shark Carcharhinus leucas (Elasmobranchii: Carcharhinidae) in the fresh waters of Sumatra, Indonesia. Biodiversitas 21 (9): 4433-4439. DOI: 10.13057/biodiv/d210962.

Heupel M. 2009. Carcharhinus melanopterus. The IUCN Red List of Threatened Species 2009: e.T39375A10219032. DOI 10.2305/IUCN.UK.2009-2.RLTS.T39375A10219032.en.

Heupel MR. 2010. Sharks. In: Breed MC, Moore J. (eds.). Encyclopedia of Animal Behavior. 2nd ed, Vol 3. Academic Prees, Oxford. DOI: 10.1016/B978-0-12-809633-8.01211-5.

Heupel MR, Knip DM, Simpfendorfer CA, Dulvy NK. 2014. Sizing up the ecological role of sharks as predators. Mar Ecol Prog Ser 495: 291-298. DOI: 10.3354/meps10597

Heupel MR, Papastamatiou YP, Espinoza M, Green ME, Simpfendorfer CA. 2019. Reef shark science-key questions and future directions Frontier Mar Sci 6 (12): 1-14. DOI: 10.3389/fmars.2019.00012.

Hughes TP, Rodrigues MJ, Bellwood DR, Ceccarelli D, Hoegh-Guldberg O, McCook L, Moltschaniwskyj N, Pratchett MS, Steneck RS, Willis B. 2007. Phase shifts, herbivory, and the resilience of coral reefs to climate change. Curr Biol 17 (4): 360-365. DOI 10.1016/j.cub.2006.12.049.

Ichsan M, Pridina N, Mukharror DA. 2016. Pariwisata Penyelaman Ikan Hiu di Perairan Morotai, Maluku Utara, Indonesia. Prosiding Simposium Hiu dan Pari. Kementerian Kelautan dan Perikanan WWF-Indonesia, Jakarta.

IGFA. 2001. Database of IGFA Angling Records until 2001. International Game Fish Association, Fort Lauderdale, USA.

Iqbal M, Setiawan A, Yustian I. 2019. First inland record of bull shark Carcharhinus leucas (Carcharhiniformes: Carcharhinidae) in Indonesian Borneo. Ecologica Montenegrina 24: 52-57.

Juhel J-B, Vigliola L, Mouillot D, Kulbicki M, Letessier TB, Meeuwig JJ, Wantiez L. 2017. Reef accessibility impairs the protection of sharks. J Appl Ecol 55 (2): 673-683. DOI: 10.1111/1365-2664.13007.

Kulbicki M, Guillemot N, Amand M. 2005. A general approach to length weight relationships for New Caledonian lagoon fishes. Cybium 29 (3): $235-252$.

Lindeman K, Anderson W, Carpenter KE, Claro R, Cowan J, PadovaniFerreira B, Rocha LA, Sedberry G, Zapp-Sluis M. 2016d. Lutjanus cyanopterus. The IUCN Red List of Threatened Species 2016: e.T12417A506633. DOI: 10.2305/IUCN.UK.2016-1.RLTS.T12417A506633.en.
Lindeman K, Anderson W, Claro R, Cowan J, Padovani-Ferreira B, Rocha LA, Sedberry G. 2016c. Rhomboplites aurorubens. The IUCN Red List of Threatened Species 2016: e.T190138A1941553. DOI: 10.2305/IUCN.UK.2016-1.RLTS.T190138A1941553.en.

Lindeman K, Anderson W, Carpenter KE, Claro R, Cowan J, PadovaniFerreira B, Rocha LA, Sedberry G, Zapp-Sluis M. 2016b. Lutjanus synagris. The IUCN Red List of Threatened Species 2016: e.T194344A2317059. DOI: 10.2305/IUCN.UK.20161.RLTS.T194344A2317059.en.

Lindeman K, Anderson W, Carpenter KE, Claro R, Cowan J, PadovaniFerreira B, Rocha LA, Sedberry G, Zapp-Sluis M. 2016a. Lutjanus synagris. The IUCN Red List of Threatened Species 2016: e.T194344A2317059. DOI: 10.2305/IUCN.UK.20161.RLTS.T194344A2317059.en.

Link JS, Bell RJ, Auster PJ, Smith BE, Overholtz WJ, Methratta ET, Pranovi F, Stockhausen WT. 2012. Food web and community dynamics of the Northeast U.S. large marine ecosystem. US Dept Commer, Northeast Fish Sci Cent Ref Doc 12-15. DOI: 10.13140/2.1.1051.5203.

Lynam CP, Llope M, Möllmann C, Helaouët P, Bayliss-Brown GA, Stenseth NC. 2017. Interaction between top-down and bottom-up control in marine food web. Proc Natl Acad Sci USA 114 (8): 19521957. DOI: $10.1073 /$ pnas.1621037114.

Maire E, Villéger S, Graham NAJ, Hoey AS, Cinner J, Ferse SCA, Aliaume C, Booth DJ, Feary DA, Kulbicki M, Sandin SA, Vigliola L, Mouillot D. 2018. Community-wide scan identifies fish species associated with coral reef services across the Indo-Pacific. Proceedings Biol Sci. 285 (1883): 20181167. DOI: 10.1098/rspb.2018.1167.

Maureaud A, Hodapp D, van Denderen PD, Hillebrand H, Gislason H, Dencker TS, Beukhof E, Lindegren M. 2019. Biodiversity-ecosystem functioning relationships in fish communities: biomass is related to evenness and the environment, not to species richness. Proceedings of the Royal Society B 286: 20191189. DOI: 10.1098/rspb.2019.1189.

McCauley DJ, Young HS, Dunbar RB, Estes JA, Semmens BX, Micheli F. 2012. Assessing the effects of large mobile predators on ecosystem connectivity. Ecol Appl 22 (6):1711-1717.

McClanahan TR, Abunge CA. 2015. Perceptions of management options and the disparity of benefits among stakeholder communities and nations of southeastern Africa. Fish Fish 17 (2): 417-437. DOI: $10.1111 /$ faf.12118.

McClanahan TR, Graham NAJ, MacNeil MA, Muthiga NA, Cinner JE, Bruggemann JH, Wilson SK. 2011. Critical thresholds and tangible targets for ecosystem-based management of coral reef fisheries. PNAS 108 (41): 17230-17233. DOI: 10.1073/pnas.1106861108.

McClanahan TR, Jadot C. 2017. Managing coral reef fish community biomass is apriority for biodiversity conservation in Madagascar. Mar Ecol Prog Ser 580: 169-190.

McClanahan TR, Maina JM, Graham NAJ, Jones KR. 2016. Modeling reef fish biomass, recovery potential, and management priorities in the Western Indian Ocean. PLoS ONE 11 (5): e0154585. DOI: 10.1371/journal.pone.0154585.

Ministry of Marine Affairs and Fisheries (MMAF), Republic of Indonesia and USAID Sustainable Ecosystems Advanced (SEA) Project. 2018. State of the Sea: Indonesia, Volume Three: A Journey Through Eastern Indonesia: USAID SEA Project-Sites and Activities, Jakarta

Moran B, Puebla O. 2020. Hypoplectrus maya. The IUCN Red List of Threatened Species 2020: e.T16759101A86415416. DOI: 10.2305/IUCN.UK.2020-2.RLTS.T16759101A86415416.en.

Mouillot D, Parravicini V, Bellwood DR, Leprieur F, Huang D, Cowman PF, Albouy C, Hughes TP, Thuiller W, Guilhaumon F. 2016. Global marine protected areas do not securethe evolutionary history of tropical corals and fishes. NatCommun 7: 10359. DOI: $10.1038 /$ ncomms 10359

Mourier J, Maynard J, Parravicini V, Ballesta L, Clua E, Domeier ML, Planes S. 2016. Extreme inverted trophic pyramid of reef sharks supported by spawning groupers. Curr Biol 26: 2011-2016. DOI: 10.1016/j.cub.2016.05.058

Mourier J, Planes S. 2013. Direct genetic evidence for reproductive philopatry and associated fine-scale migrations in female Blacktip Reef Sharks (Carcharhinus melanopterus) in French Polynesia. Mol Ecol 22 (1): 201-214. DOI: 10.1111/mec.12103.

Mukharror DA, Baiti IT, Ichsan M, Pridina N, Triutami S. 2017. Correlation between existence of reef sharks with abundance of reef fishes in South Waters of Morotai Island (North Moluccas). IOP Conf 
Ser: Earth Environ Sci 89: 012006. DOI: 10.1088/17551315/89/1/012006

Mukharror DA, Susiloningtyas D, Handayani T. 2020. Blacktip Reefshark (Carcharhinus melanopterus) Movement Displays during Interaction with SCUBA Diver in Morotai Waters, Maluku Utara, Indonesia. J Comput Theor Nanosci 17: 1-5. DOI: 10.1166/jctn.2020.8799.

Mukharror DA, Susiloningtyas D, Handayani T, Pridina N. 2019. Blacktip reefshark (Carcharhinus melanopterus) individual's identification in Morotai Waters using its fin's natural markings. Int Conf Sci Appl Sci (ICSAS) AIP Conf Proc 2202: 020085. DOI 10.1063/1.5141698

Mukharror DA, Triutami S, Sriati, Yuliadi LP, Ichsan M. 2018. Correlation Between Existence of Reef Sharks with Abundance of Reef Fishes: Carnivore and Herbivore Type in South Waters of Morotai Island (North Moluccas). International Conference of Marine Biology. Denpasar, Bali, Indonesia, December 2016.

Mumby PJ, Dahlgren CP, Harborne AR, Kappel CV, Micheli F, Brumbaugh DR, Holmes KE, Mendes JM, Broad K, Sanchirico JN, Buch K, Box S, StoZe RW, Gill AB. 2006. Fishing, trophic cascades, and the process of grazing on coral reefs. Science 311: 98-101. DOI 10.1126/science.1121129

Myers R, Choat JH, Abesamis R, Clements KD, McIlwain J, Nanola C, Rocha LA, Russell B, Stockwell B. 2012. Acanthurus chronixis. The IUCN Red List of Threatened Species 2012: e.T177966A1505213. DOI: 10.2305/IUCN.UK.2012.RLTS.T177966A1505213.en.

Nabil WA, Habibah I, Aryochepridho, Trijoko. 2018. Short Communication: Caught fish species diversity of South Morotai, North Maluku, Indonesia. Ocean Life 2 (1): 33-36. DOI: 10.13057/oceanlife/o020105

Osgood GJ, Baum JK. 2015. Reef sharks: Recent advances in ecological understanding to inform conservation. J Fish Biol 87 (6): 1489-1523. DOI: $10.1111 / \mathrm{jfb} .12839$

Pridina N. 2015. Distributions of Reef Shark based on the Characteristic of Habitat on Morotai Waters, North Maluku. [Thesis]. Universitas Padjadjaran, Sumedang.

Purba NP, Herawati H, Dewanti LP, Faizal I, Apriliani IM, Martasuganda MK. 2019. Development of Morotai Island-North Maluku based on oceanographic-ecosystem condition. Jurnal Perspektif Pembiayaan dan Pembangunan Daerah 7 (3): 305-314

Puk LD, Ferse SCA, Wild C. 2016. Patterns and trends in coral reef macroalgae browsing:a review of browsing herbivorous fishes of the Indo-Pacific. Rev Fish Biol Fish 26 (1): 53-70. DOI: 10.1007/s11160015-9412-z.

Randall JE. 1977. Contribution to the biology of the whitetip reef shark (Triaenodon obesus)". Pac Sci 31 (2): 143-164

Retnoningtyas H, Yuwanda DP, Karepesina H, Yulianto I. 2017. Report: Fisheries Scoping Survey: North Maluku Province. USAID SEA Project-WCS, Jakarta.

Rhodes KL, Baremore I, Graham RT. 2019. Grouper (Epinephelidae) spawning aggregations affect activity space of grey reef sharks, Carcharhinus amblyrhynchos, in Pohnpei, Micronesia. PLoS One 14 (8): e0221589. DOI: 10.1371/journal.pone.0221589.

Rizzari JR. Bergseth BJ, Frisch AJ. 2015. Impact of conservation areas on trophic interactions between apex predators and herbivores on coral reefs. Conserv Biol 29: 418-429. DOI: 10.1111/cobi.12385.

Roberts C. 1996a. Anthias regalis. The IUCN Red List of Threatened Species 1996: e.T39302A10185766. 10.2305/IUCN.UK.1996.RLTS.T39302A10185766.en.

Roberts C. 1996b. Plectranthias chungchowensis. The IUCN Red List of Threatened Species 1996: e.T17604A7182421. DOI: 10.2305/IUCN.UK.1996.RLTS.T17604A7182421.en.

Robertson R, Allen G, Dominici-Arosemena A, Edgar G, Rivera F, Merlen G. 2010. Paralabrax albomaculatus. The IUCN Red List of Threatened Species 2010: e.T183769A8173211. DOI: 10.2305/IUCN.UK.2010-3.RLTS.T183769A8173211.en.

Robertson R, Carpenter KE. 2019. Hypoplectrus liberte. The IUCN Red List of Threatened Species 2019: e.T141363430A141563173. DOI: 10.2305/IUCN.UK.2019-3.RLTS.T141363430A141563173.en.
Robinson JPW, Williams ID, Edwards AM, McPherson J, Yeager L, Vigliola L, Brainard RE, Baum JK. 2016. Fishing degrades size structure of coral reef fish communities. Glob Change Biol 23 (3): 114. DOI: $10.1111 / \mathrm{gcb} .13482$.

Roff G, Doropoulos C, Rogers A, Bozec Y-M, Krueck NC, Aurellado E, Priest M, Birrell C, Mumby PJ. 2016. Review the ecological role of sharks on coral reefs. Trend Ecol Evol 31 (5): 395-589. DOI: 10.1016/j.tree.2016.02.014.

Ruppert JLW, Fortin M-J, Meekan MG. 2016. The ecological role of sharks on coral reefs: Response to Roff et al.. Trends Ecol Evol 31: 586-587. DOI: $10.1016 /$ j.tree.2016.05.003

Schmitz OJ, Hawlena D, Trussell GC. 2010. Predator control of ecosystem nutrient dynamics. Ecol Lett 13: 1199-1209. DOI: 10.1111/j.1461-0248.2010.01511.x

Smale MJ. 2009. Triaenodon obesus. The IUCN Red List of Threatened $\begin{array}{llll}\text { Species } & \text { 2009: } & \text { e.T39384A10188990. }\end{array}$ 10.2305/IUCN.UK.2005.RLTS.T39384A10188990.en.

Smith-Vaniz WF, Carpenter KE, Jiddawi N, Borsa P, Obota C, Yahya S. 2018a. Pseudocaranx chilensis. The IUCN Red List of Threatened $\begin{array}{llll}\text { Species } & 2018 \text { : } & \text { e.T20433018A67871620. }\end{array}$ 10.2305/IUCN.UK.2018-2.RLTS.T20433018A67871620.en.

Smith-Vaniz WF, Carpenter KE, Borsa P, Jiddawi N, Yahya S, Obota C. 2018b. Trachurus indicus. The IUCN Red List of Threatened Species 2018: e.T20437726A46664154. DOI: 10.2305/IUCN.UK.20182.RLTS.T20437726A46664154.en.

Smith-Vaniz WF, Sidibe A, Nunoo F, Lindeman K, Williams AB, Quartey R, Camara K, Carpenter KE, Montiero V, de Morais L, Djiman R, Sylla M, Sagna A. 2015. Trachurus trachurus. The IUCN Red List of Threatened Species 2015: e.T198647A43157137. DOI: 10.2305/IUCN.UK.2015-4.RLTS.T198647A43157137.en.

Smith-Vaniz B, Robertson R, Dominici-Arosemena A, Molina H, Salas E, Guzman-Mora AG. 2010a. Rypticus courtenayi. The IUCN Red List of Threatened Species 2010: e.T183621A8146180. DOI: 10.2305/IUCN.UK.2010-3.RLTS.T183621A8146180.en.

Smith-Vaniz B, Robertson R, Dominici-Arosemena A, Molina H, Salas E, Guzman-Mora AG. 2010b. Serranus socorroensis. The IUCN Red List of Threatened Species 2010: e.T183852A8188656. DOI: 10.2305/IUCN.UK.2010-3.RLTS.T183852A8188656.en.

Smith-Vaniz B, Robertson R, Dominici-Arosemena A, Molina H, Salas E, Guzman-Mora AG. 2015. Pseudogramma axelrodi. The IUCN Red List of Threatened Species 2015: e.T183326A85699406. DOI: 10.2305/IUCN.UK.2015.RLTS.T183326A85699406.en.

Speed CW, Rees MJ, Cure K, Vaughan B, Meekan MG. 2019. Protection from illegal fishing and shark recovery restructures mesopredatory fish communities on a coral reef. Ecol Evol 9 (18): 10553-10566. DOI: $10.1002 /$ ece 3.5575 .

Stevenson C, Katz LS, Micheli F, Block B, Heiman KW, Perle C, Weng K, Dumbar R, Witting J. 2006. High apex predator biomass on remote Pacific Islands. Coral Reefs 26: 47-51. DOI: 10.1007/s00338-0060158-x

Vincent IV, Hincksman CM, Tibbetts IR, Harris A. 2011. Biomass and abundance of herbivorous fishes on coral reefs off Andavadoaka, Western Madagascar. West Indian Ocean J Mar Sci 10 (1): 83-99.

Wallach AD, Ripple WJ, Carroll SP. 2015. Novel trophic cascades: Apex predators enable coexistence. Trends Ecol Evol 30: 146-153. DOI: 10.1016/j.tree.2015.01.003.

Weideli OC, Mourier J, Planes S. 2015. A massive surgeonfish aggregation creates a unique opportunity for reef sharks. Coral Reefs 34: 835. DOI: $10.1007 / \mathrm{s} 00338-015-1290-2$

Wilson JR, Green AL. 2009. Biological Monitoring Methods for Assessing Coral Reef Health and Management Effectiveness of Marine Protected Areas in Indonesia. Version 1.0. TNC Indonesia Marine Program Report 1/09, Indonesia.

Wilson EE, Wolkovich EM. 2011. Scavenging: How carnivores and carrion structure communities. Trends Ecol Evol 26: 129-135. DOI: $10.1016 /$ j.tree.2010.12.011. 